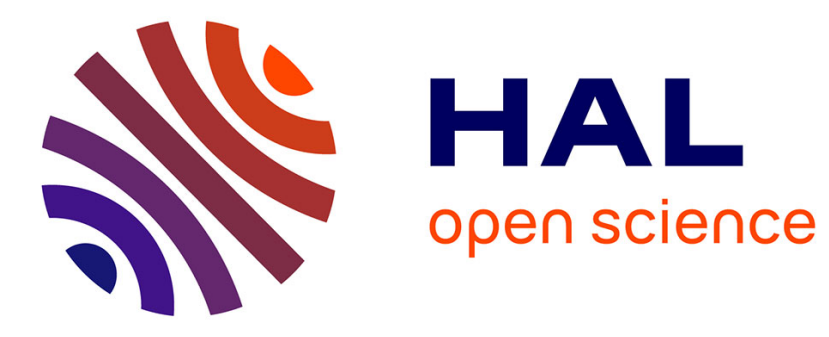

\title{
Integration of immigrants in France: a historical perspective \\ Jacques Barou
}

\section{To cite this version:}

Jacques Barou. Integration of immigrants in France: a historical perspective. Identities. Global studies in culture and power, 2014, What remains of the Nationa Models of Integration?, 21 (6), pp.642-657. 10.1080/1070289X.2014.882840 . halshs-01081685

\section{HAL Id: halshs-01081685 https://shs.hal.science/halshs-01081685}

Submitted on 18 Feb 2018

HAL is a multi-disciplinary open access archive for the deposit and dissemination of scientific research documents, whether they are published or not. The documents may come from teaching and research institutions in France or abroad, or from public or private research centers.
L'archive ouverte pluridisciplinaire HAL, est destinée au dépôt et à la diffusion de documents scientifiques de niveau recherche, publiés ou non, émanant des établissements d'enseignement et de recherche français ou étrangers, des laboratoires publics ou privés. 


\title{
Integration of immigrants in France: \\ a historical perspective
}

\begin{abstract}
This article addresses the question of integration in France. First, we introduce data on immigration, unemployment and discrimination affecting especially young French citizens of non-European descent living in poor neighbourhoods. Their experiences of these has led some of them to reject French Republican values. Has the French model of integration failed? To answer this question, we detail and analyze the historical development of this normative model and its actual policies through Durkheim's theory of integration. Durkheim showed how a society that is characterized by a certain amount of social cohesion integrates individuals and groups and how, when socio-economics or social conflicts weaken this cohesion, integration no longer works. To strengthen this hypothesis, we then examine contemporary French debates about integration and discrimination. Finally, we conclude that social inequalities in the form of urban segregation are the main reason for the failure of Republican integration.
\end{abstract}

Keywords: French model of integration; Durkheim; assimilation; accommodation; discrimination; Republican values

\section{Introduction}

France has always been an immigration country (Noiriel 1988). Most of the children and grandchildren of immigrants who arrived in the last few decades - Poles and Italians before the Second World War, Spaniards and Portuguese in the 1950s and 1960s, North Africans in the 1960s, Asians and West Africans in the 1970s and 1980s - have become French citizens. According to the 2006 French census, $25 \%$ of the population have at least one parent or grandparent who immigrated to France (INSEE 2008: 46). As shown in Table 1, the number of immigrants ${ }^{1}$ increased steadily during the second half of the $20^{\text {th }}$ century; the percentage of 
those coming from Europe decreased while the proportion of those coming from Asia and above all Africa grew.

Table 1 Immigrants to France by country of origin, 1962-1999.

\begin{tabular}{|c|c|c|c|c|c|c|c|}
\hline $\begin{array}{l}\text { Country } \\
\text { of origin }\end{array}$ & $\begin{array}{l}1962 \\
\text { per cent }\end{array}$ & $\begin{array}{l}1968 \\
\text { per cent }\end{array}$ & $\begin{array}{l}1975 \\
\text { per cent }\end{array}$ & $\begin{array}{l}1982 \\
\text { per cent }\end{array}$ & $\begin{array}{l}1990 \\
\text { per cent }\end{array}$ & $\begin{array}{l}1999 \\
\text { per cent }\end{array}$ & $\begin{array}{l}1999 \\
\text { number }\end{array}$ \\
\hline Europe & 78.7 & 76.4 & 67.1 & 57.3 & 50.4 & 45 & $\begin{array}{l}1,934,14 \\
4\end{array}$ \\
\hline Africa & 14.9 & 19.9 & 28 & 33.2 & 35.9 & 39.3 & $\begin{array}{l}1,691,56 \\
2\end{array}$ \\
\hline Algeria & 11.6 & 11.7 & 14.3 & 14.8 & 13.3 & 13.4 & 574,208 \\
\hline Morocco & 1.1 & 3.3 & 6.6 & 9.1 & 11 & 12.1 & 522,504 \\
\hline Tunisia & 1.5 & 3.5 & 4.7 & 5 & 5 & 4.7 & 201,561 \\
\hline $\begin{array}{l}\text { Sub- } \\
\text { Saharan } \\
\text { Africa }\end{array}$ & 0.7 & 1.4 & 2.4 & 4.3 & 6.6 & 9.1 & 393,289 \\
\hline Asia & 2.4 & 2.5 & 3.6 & 7.9 & 11.4 & 12.7 & 549,994 \\
\hline Others & 4 & 1.2 & 1.3 & 1.6 & 2.3 & 3 & 130,394 \\
\hline Total & 100 & 100 & 100 & 100 & 100 & 100 & \\
\hline Number & 2861280 & 3281060 & 3887460 & 403036 & 4165952 & 4306094 & $4,306,09$ \\
\hline
\end{tabular}




\begin{tabular}{|l|l|l|l|l|l|l|l|}
\hline & & & & & & & 4 \\
\hline
\end{tabular}

Source: INSEE 2001

The economic situation over the same period deteriorated. Since the beginning of the 1980s, the rate of unemployment has never been lower than 7\%. By contrast, in 2012, the global rate is around 10\%. Unemployment is particularly high for less qualified workers, among whom are many immigrants. Almost 30\% of Algerian immigrants were unemployed (CAS 2012: 7). According to a report published by the High Comity for Integration (HCI 2011: 14), French citizens with parents immigrating from non-European countries are twice as likely $(24.2 \%)$ to be unemployed than other citizens. Those who do not hold a diploma are particularly affected (40.5\%). Qualified citizens of non-European origin, however, are significantly more affected by unemployment than qualified people of French descent $(14.1 \%$ against $4.6 \%$ ). These figures show the presence of discrimination between certain categories of French citizens, even when they are relatively skilled. Young people of Sub-Saharan and Maghrebian origin looking for work and a flat to rent - if they can afford to - are the main target of racism. It is thus increasingly difficult for immigrants and their descendants to find their place in French society, whatever policies are implemented by socialist or conservative governments.

This indicates that the so-called French (Republican) model of integration has become less effective. This civic and assimilationist model stands for one of the three models of citizenship referred to in the introduction to this volume. Civic-territorial refers to a voluntaristic political identification of the citizen with the nation, which exiles cultural difference to the private sphere. Assimilationist means that in practice this model is accompanied by a strong assimilation to dominant French values that pretend to be universal. The functionality of this political-cultural model has always been based on the socioeconomic integration of immigrants, particularly in industrial society. For this reason our hypothesis is that the crisis of the Republican model seems to be caused at root by socioeconomic problems. Nevertheless, as the preceding data show, discrimination also affects relatively skilled French citizens. Therefore, we must first discuss such ethnic-cultural issues in relation to the core of the Republican model. How should we treat racial discrimination as an expression of cultural difference? And before that, how do we name those who are the target of such discrimination? 
Because cultural difference is restricted to the private sphere, the concept of visible ethnic minorities, proposed by scholars like Benbassa (2011) as a way to analyze these discriminations, is not used in official texts dealing with immigration; for a long time the term racism rarely appeared in official texts and even in scientific work. The words generally used to name immigrants and their children are first and second generation immigrants, children of immigrants, French people of immigrant descent, etc. These terms are used in the surveys made by the National Institute for Statistics and Economy (INSEE) and the National Institute for Demographic Studies (INED), for example in "Trajectoires et origins" (INED and INSEE 2010), and by a large number of researchers.

Furthermore, since 1990, there has been no more confusion between immigrants and foreigners in the French census. Official surveys now distinguish two categories of immigrants: those who have kept their foreign citizenship and those who came to France as foreigners and obtained French citizenship later. In the 2008 census, the number of immigrants was 5,342,000, among whom 3,715,000 were foreigners. Their children, if they are born in France, are not considered immigrants. Under the 1889 law introducing jus soli they automatically benefit from French nationality when they come of age. Since the French census does not collect data on ethnic origin or religious belief, they become statistically invisible.

In spite of the arguments developed by scholars such as Simon (2008) and Héran (2010) advocating the need to identify descendants of immigrants in order to form a more precise idea of their social situation and get a better measure of the discrimination they experience, most decision makers and experts continue to refuse to use ethnic or racial terms for French citizens. ${ }^{2}$

The reluctance to give accord official status to ethnic minorities can be explained by the Republican principles of unity and equality, which have always been shared by a large number of citizens - among them those of foreign origin. Article 1 of the Constitution of the Fifth Republic proclaims the French State as a nation-state "one and indivisible", prohibiting the recognition of any organizational infrastructure based on particular ethnic, territorial or religious identities on the basis that it would threaten these principles. Founding political parties to defend the interests of particular social, ethnic, linguistic or religious groups is not forbidden. However, the French political system favours national political parties over regional, ethnic or linguistic ones.

This context explains why it is difficult to imagine multicultural policies in France, in spite of the increasing cultural diversity of French society (Doytcheva 2005). Decision makers 
and scholars cannot deny this reality, yet many of them consider that multiculturalism is not an appropriate policy in a centralized nation state like France (Wihtol de Wenden 2003, Weil 2011). Instead, it seems to be more consistent with federal states such as Canada, where different cultural groups have been used to sharing power for a long time. Ultimately, the historical experience of dealing with cultural difference in France appears more important for the elaboration of integration policies than the example of other nations. However, French immigration history has been rather complex and paradoxical.

\section{Integration, assimilation, accommodation: sociological theory and Republican experience}

France received large waves of immigrants in many decades of the $20^{\text {th }}$ century; there were around 300,000 newcomers per year in the 1920s and 1960s. However, nobody seemed worried about their integration. The word "integration" itself was rarely used, either in the press or in political discourse. Scholars did not refer to integration as concept. Ultimately, there was no will to develop a policy of integration: the process of integration seemed to be working by itself. Most immigrants were employed in industry, construction or civil engineering, and had been recruited in times of economic growth. This socio-professional situation ensured their social integration into the French working class and gave them a corresponding collective consciousness - i.e. class consciousness - that guided them through class conflicts and their participation in French politics via the trade unions and the left-wing parties. This process, from professional and social integration to political participation, illustrates Durkheim's theory of integration and seems to demonstrate the precision of his analyses. Integration in labour is the main condition of integration in a modern society.

\section{Forms of integration and social cohesion: the Durkheimian origins of the French model}

If we understand "integration" with respect to the act of "integrating" in a large sense as "incorporation as equals into society or an organization of individuals of different groups, as races", 3 this is not far from the concept developed in Durkheimian sociology. This concept - fundamental for Durkheim's theory of social bonds - pervades many of his works from his thesis The Division of Labour in Society, defended in 1893 (Durkheim 1984), to his last book The Elementary Forms of Religious Life, published in 1912 (Durkheim 1995). From a general point of view, integration is a process that consists in adding one element to a group of others 
in order to form a coherent unity. This process answers the following question: How do individuals achieve consensus, the prerequisite of all social existence? They do so because achieving consensus involves the existence of shared beliefs and practices and the approval of a common purpose; it assumes the existence of a principle of solidarity.

Durkheim distinguishes two types of solidarity: mechanical and organic. In the first, individuals differ little from each other. They harbour the same emotions, they hold the same values and they believe in the same religion. Society draws its cohesion from this similarity. In the second, cohesion is achieved by differentiation. Free individuals pursuing different functions are united by their complementary roles. They are interdependent of each other in spite of their differences. For Durkheim, these distinctions are both conceptual and historical. "Primitive societies" and European societies in earlier periods were mechanical. Modern society is organic.

In analysing the nature of contractual relationships as fundamental for the cohesion of modern society, Durkheim discovered that organic solidarity could be maintained only if certain aspects of mechanical solidarity remained. The members of a modern society need to hold certain beliefs in common. Without these collective beliefs, no contractual relationship that is based only on self-interest could have any force. If the collective consciousness of belonging to a society is too weak, social values will break down. Individuals find themselves without norms in a state that Durkheim named "anomie". The growing heterogeneity of modern societies means that they will have to take up this challenge, otherwise the process of integration will collapse and social unrest will spread.

Durkheim illustrated this theory in his study of suicide (Durkheim 1951). By analyzing statistical data on suicide rates, comparing them with religious beliefs, age, sex, marital status and economic changes, he concluded that the rate of suicide was higher among those who are poorly integrated into social groups. Committing suicide appeared to be a symptom of unrest and frustration affecting individuals who lacked social support because they did not belong to a well-integrated group. Yet, integration also characterizes a society as a whole. A society is well-integrated if it shows a high degree of cohesion and a strong feeling of collective consciousness.

The concept of collective consciousness was an ongoing concern for Durkheim, not only as a sociologist but also as a citizen involved in the problems of his time. He believed that collective consciousness was responsible for both the integration of every individual into society and the cohesion of the group itself. At a time when economists were underlining the growing competition between individuals to satisfy their egotistical interests, and when 
psychologists were describing people as mainly governed by personal impulses, the question of the social bond appeared crucial to maintaining social cohesion. However, the need to share a common culture to avoid breaking the social bond can lead to the cultural assimilation of newcomers.

Here it is necessary to distinguish clearly between integration and assimilation. Assimilation erodes both the public and the private differences between and among groups (Kazal 1995). It may occur in the absence of public policy, or as a direct or indirect result of it. Immigrants are assimilated through their acculturation, which requires that they adopt the "majority culture" and are absorbed into it. In contrast, integration does not require cultural conformity in public and private life. Its aim is to turn a blind eye to difference for public purposes. This involves, on the one hand, a kind of privatization of ethnic, cultural and religious differences, and, on the other hand, a certain level of homogeneity in public life: a common language and shared values are required.

Finally, education, was in France in particularly the main way of achieving and sharing a collective consciousness. It was attractive, given the fact that it led to intergenerational upward social mobility. Because many immigrants were illiterate, French public education was an opportunity for their children. For this reason, first generation immigrants accepted the fact that their sons and daughters would gradually lose their mother tongue and adopt French culture. This was not only the result of a strengthened assimilation process. These second and third generations themselves perceived French culture as a common centre of reference in the public sphere and considered their culture of origin as dominant in the private sphere of family and community ties.

These behaviours evoke Simmel's description of the stranger who resides both inside and outside society. They also illustrate his theory of "the intersection of social circles" (Simmel 2009), according to which individuals belong to different social circles and are the result of the interactions between them. Simmel agrees with Durkheim when he considers that the division of labour in society offers individuals many more opportunities to enrich their personality by developing relations with a larger number of social circles. The aim of education is to give individuals the means to enlarge their social networks, not to push them to abandon their primary ones.

How can we now use these theoretically framed notions of integration, assimilation and education to analyze the integration of immigrants into modern French society?

\section{Between assimilation and accommodation: discourse and reality}


Until the end of the 1970s, various censuses showed that the children of immigrants experienced greater upward social mobility in comparison to their parents. The main reasons were the higher level of education they received in public schools (INSEE 2005) and French economic prosperity. A truly intergenerational social mobility into the French working class had developed (Verret 1999), of which a large number of immigrants could take advantage.

However, there were periods of crisis during the decades of economic growth. The most crucial was that of the 1930s, which saw growth in unemployment and an increase in violent xenophobia among the French population, including the working class (Schor 1985). Yet this crisis also provided a political answer in support of the integration of immigrants. In 1936, the government of the Front Populaire created a Junior Ministery Office to deal with immigration. Its existence was brief but it took some important measures in facilitating the acquisition of French citizenship (Weil 2005).

Nevertheless, during the years preceding the Second World War, French immigration policy was influenced by racist ideas and the process of integration was turned into coercive assimilation. In the particular climate of the economic crisis and the impending arrival of refugees, France adopted a national and racial quota policy based on a list of "races and peoples" constructed on a hierarchy of assimilability. The main theorist behind this new policy was Georges Mauco, a scholar who in 1932 published his doctoral thesis entitled "Les Etrangers en France. Etude géographique sur leur rôle dans l'activité économique". ${ }^{4}$ In considering migration issues within the evolution of the French population, he analyzed the "assimilability" of immigrants according to their origins. He defined a composite score based on the criteria of assimilability that put Arab workers on the lowest rung of the ladder, and Italians, Swiss and Belgians at the top (Weil 2003). Although Mauco supported the Vichy government until 1944, his influence remained important after the Second World War. When the government of General de Gaulle created a High Population Council (HPC) in April 1945, Mauco was named its secretary general, a position he held until 1970. This did not prevent the HPC producing an immigration law, the 2 November 1945 Act that organized an egalitarian, individualist, and progressive system for issuing permits without selecting on the basis of ethnicity. This act still forms the framework of French immigration policy. Nevertheless, ideas about the assimilability of certain immigrant groups and the non-assimilability of others have not entirely vanished. In fact, they returned with force in the context of the economic problems of the 1990s and 2000s. 
In spite of official declarations of the equality of all immigrants there was for a long time among those civil servants entrusted with immigration policy a trend to confuse integration and assimilation, and to promote specific treatments of those immigrants considered difficult to assimilate (Laurens 2009). Immigrants from formerly colonized countries in particular received treatment different from than those from Southern Europe. They were the targets of increased social control, although, the French authorities did not establish an integration policy towards these immigrants.

However, their integration into the labour market was not particularly efficient. Because of their low professional qualifications many of them had no stable jobs. Even in times of economic growth, their unemployment rate has always been higher than the average. These immigrants often held marginal jobs in the industrial and service sectors. Thus, their working class consciousness was not particularly strong. Many cultivated the "myth of return" (Sayad 1999) and hoped to be able to create independent businesses with their savings.

According to the French authorities, the governments of their countries and their own self-understanding, these immigrants remained foreigners in France; the question of their integration was of no importance. France delegated social and cultural policies to its consulates and those associations controlled by the governments of the countries of origin. Accommodation seems to be the best description of the policies implemented towards these workers, who have resided in France for long periods while their families remained in their home countries. Accommodation can be defined as "adaptation and adjustment to the special interests and needs of groups" (O'Leary and McGarry 2012: 14). However, as these individuals were a priori considered by the receiving society as unassimilable, their only needs and interests were to transfer remittances to their countries and finally to go back home. French public policy was seeking to help them adapt to conditions of life they had not really chosen.

\section{The return of integration: immigrants and "classes populaires"}

There was no real political debate about integration until the 1980s. The French government appointed a Secretary of State for immigrant workers in 1975. Its main role was not integration, but rather the control and reversal of migration flows; it was also responsible for housing issues and cultural matters. In fact, in spite of the return allowances given by French authorities under the last government of Raymond Barre (1978-1981), very few families did return home. On the contrary, several workers with families still living in the countries of 
origin took advantage of a more flexible immigration law and brought them to France. Wives and children of immigrants already settled in France represented the largest number of newcomers in the 1980s and 1990s. They accounted for about $60 \%$ of the 120,000 new immigrants registered on average per year. These families settled in public housing in working class neighbourhoods that were characterized by the consequences of the economic crisis: high rates of unemployment, problems with delinquency, and residential and ethnic segregation. Those households with sufficiently high incomes tried to leave for urban areas with a higher living standard. While the majority of these residents were of French or European origin, most of the immigrants of non-European descent had to remain in the poor neighbourhoods.

The children of these mostly unskilled and illiterate workers, recently arrived in France or born in the country, were faced with the failing schools in segregated establishments that were characterized by low rates of success. Because they dropped out of the education system without a diploma, their social upward mobility was also very low. Those who did gain diplomas often experienced racial and spatial discrimination from employers who refused to recruit them. Thus, this second generation of non-European immigrants, mostly of Maghrebian descent, understood that they had been forced to become culturally French while at the same time being socially excluded (Dubet and Lapeyronnie 1992).

As a result, it was not surprising that many of them were among the young people who took part in the first urban riots in the suburbs of Lyon at the beginning of the 1980s. Such events reopened the debate about the future of this second generation - discovered by the public as a new urban and social problem - and to stir up the question of their integration. In addition, the new government of François Mitterrand, dominated by socialists, came into power at. The time was right to approach the issue.

Scholars (Dubet 1987, Bachmann 1989) and politicians like Hubert Dubedout, then mayor of Grenoble and first president of the National Commission for the social development of poor neighbourhoods, agreed that the problem was above all a social one. In 1982, a new policy was made to improve the living conditions of those districts affected by social unrest. This policy did not target explicitly ethnic but rather urban minorities of poor neighbourhoods chosen according to social and spatial criteria. Its aim was to make them similar to any other district by eliminating all their negative aspects: poor architecture, lack of public facilities, unemployment, delinquency, violence, poor performances at school and so on (Donzelot 1991). Named the Politique de la ville, similar to the British "inner city policy", this policy 
has been in place for thirty years, irrespective of the government in power. It may be considered the hard core of integration policy. However, according to the Republican principle of equality, it has never emphasised the ethnic composition of those living in these chosen districts, even though a large part of them are of North-African or Sub-Saharan origin.

Ten years later, the results of this urban policy were not insignificant (Estèbe and Donzelot 2004). Housing had been considerably improved, the neighbourhoods benefited from numerous public facilities and inhabitants' associations had been encouraged to take initiatives. Yet the rate of unemployment was still much higher than the national average (Fitoussi et al. 2004) and delinquency had worsened. Furthermore, new forms of religious claims were made in public. In high schools, some Muslim girls demanded to wear a veil. In a secular country like France, such demands are a provocation and have always led to sharp debates. At the same time, Muslim associations became more numerous, and called for the building of mosques and the ability to respect their religious rites. Indeed, a few religious leaders stressed the priority of obedience to God over the laws of the Republic. This amplified the fear among decision makers of religious proselytism organized by closed organizations that would convert radicalize young French citizens to reject the Republican principles of secularity. Less ideologically, scholars analyzed the variance of emerging forms of an Islam in the West between neo-communitarian, secularized forms that sought social recognition at the community level of the French banlieues, and the more marginal forms of Islamistic groups (Kepel 1997).

The public authorities decided to define a corresponding model of integration for this new social and urban context. In 1990, the French government created a "High Council for Integration", whose members were researchers, politicians, activists and important individuals of immigrant descent. The result, one year later, was the book Pour un modèle français d'intégration. ${ }^{5}$ Reflecting recent changes, the book's model first rejects the experience of assimilation related to the post-colonial period. Second, it takes a stand against the 1970s model of accommodation, which asserted that immigrants could maintain their cultural identities within French society. However, this changed position was linked to a policy of return. It is defined as such:

"Integration is not a middle-way between assimilation and insertion, but a specific process where the active participation in the national society of varied and different elements is encouraged". (1991: 32, translation JB) 
The latest definition given by the High Council for Integration in 2005 operates within the same framework:

"Neither assimilation nor insertion, integration refers to the participation of the whole French people, and not only of that of immigrant descent, in the public sphere of the national community". ${ }^{6}$ (2005: 34, translation JB)

Thus, the Republican myth of citizenship has been extensively called upon to justify the definition of the French model of integration (Favel 1998). As a result, there is a major discrepancy between, on the one hand, a political discourse that adheres to the principle of equality which justifies making few efforts to acknowledge diversity, and, on the other hand, administrative officials, local authorities and social workers who have resorted to a specific and pragmatic treatment when faced with suburban, socio-cultural and religious differences.

The High Council, however, did not take into consideration that the figures for immigrant participation, and the means by which it takes place, no longer correspond to those of national society.

Firstly, post-industrial society has abolished many unskilled jobs and created a much lower number of skilled jobs. These involve a level of education and professional qualification that immigrants rarely have. As a result, many depend on social benefits and precarious jobs. They can only transmit poor cultural capital to their children. Secondly, and at the same time, the representative organizations of the French working class have lost their socio-political influence. The French Communist Party, for a long time the standard bearer of the working class, has been considerably weakened. Today, a sector of French workers express their socio-political dissatisfaction by voting for the populist extreme right party Front national. A deep cleavage has therefore developed between French workers, among them a large number of immigrant descent, and immigrants more recently settled in France. Because the collective consciousness of the working class has almost disappeared in these desocialized banlieues rouges (red suburbs), a segment of these low educated classes populaires (urban 'underclasses') withdraws into their nationalistic or ethnic and religious communities.

\section{Contemporary debates: integration versus cultural recognition}

Twenty years after the creation of the High Council for Integration, the debate about integration and its policy remains controversial. On the one hand, the advocates of integration 
insist on the positive results of the integration process and the policies implemented. Indeed, socio-demographic surveys carried out by the INED (Tribalat 1995) indicate an overall improvement in the living conditions of immigrants and a rising level of education from one generation to the next. Although children and sometimes grandchildren of immigrants are more affected by unemployment than natives, they are much more skilled and educated than their parents, and a significant proportion of them hold positions with responsibilities in the economic and political fields. A large number of immigrants communicate mostly in French, and their children and grandchildren often no longer speak their language of origin. The lifestyles and social ambitions of these people increasingly correspond to those of other citizens. Furthermore, these surveys show that immigrants and their descendants share a certain number of common values with the native French population. A significant number consider themselves more as citizens of their country of settlement than as members of their country of origin.

These findings are strengthened by a comparative survey of Muslims undertaken in four European countries: France, the UK, Germany and Spain (Pew Research Centre 2006). This survey first underlines the fact that France has the largest Muslim population in Europe, over five million. French Muslims overall expressed the same opinions as Muslims of other European countries on social questions such as "fear of unemployment" (84\% versus $78 \%$ to $83 \%$ in the three other countries) and "concerns about their future" (38\% versus $28 \%$ to $48 \%$ ). In contrast, they differed strongly on questions of identity: $42 \%$ of French Muslims consider themselves first as national citizens (and not as Muslim), against only 7\% in the UK, $13 \%$ in Germany and 3\% in Spain. It seems that Muslims living in France are absorbing the secular lifestyles of other French citizens. A larger majority wanted to adopt national customs rather than being distinct: $78 \%$ in France compared to $41 \%$ in the UK, $30 \%$ in Germany and $53 \%$ in Spain. They agree with the French attitude of refusing "le communautarisme"; that is, they are sceptical about immigrants' withdrawal into ethnic communities where solidarity is limited to the own group.

Among researchers who support the concept of integration, some criticize politicians and other decision makers for presenting the national model of integration as normative and for believing that immigrants must adopt it without question. They distinguish between, on the one hand, integration as a process that depends on social conditions that public powers are not always able to create, and, on the other hand, integration as an order to conform to existing standards (Schnapper 2007). Those who receive such an order without having the corresponding conditions to participate in social life, are forced to reject integration. Other 
authors, like Beaud and Amrani (2004), tackle the integration perspective of the children of immigrants that underline the contradictions with which they daily have to live.

In contrast to these positions, there are scholars who think that integration is no longer an appropriate concept for thinking about contemporary French society. Without supporting a multicultural model, they emphasize that immigrants and their children need cultural recognition and that the failure of integration is not due to a missing will or ability of the immigrants and their children to integrate French society. In fact, according to these authors, it is the result of a wide process of social exclusion and racial discrimination. Cultural differences should not be denied but taken into account in public policies (Wieviorka 2001 and in this issue).

This debate about integration has been followed by one about racial discrimination. For a long time, the French authorities believed that immigrants, for whom the acquisition of French citizenship would have been easy, had the same opportunities for success in French society as natives, because they have the same social and civil rights. Yet sociological studies at the end of the 1990s began to underline the presence of racial discrimination in access to work, housing or education (De Rudder, Poiret and Vourc'h 2000). Since then, French governments have decided to distribute information in order to fight racial discrimination and give victims the chance to go to law.

In spite of these public initiatives, the high percentage of unemployment persists among the youth of North-African and Sub-Saharan origin. Increasing residential segregation also obstructs multi-ethnic cohabitation. Is the "Republican school" still able to produce patterns of socialization in the poor neighbourhoods that correspond to the rules and values of French society? In fact, there is a growing gap between school education and the family education implemented by parents who belong to traditional African cultures (Barou 2012). In the suburbs school performance is much weaker than average, discipline is no longer applied and the schools cannot convey the moral values or common rules they need for the cohesion of their local societies. In this context, delinquent activities appear to some youths as the most profitable way to earn money. The urban riots of November 2005 are the most visible sign of the French failure to integrate the marginalized among its immigrated minorities (Lagrange and Oberti 2006, Kokoreff and Lapeyronnie 2013: 37-40 and 72-78).

In order to meet such difficulties, the French government decided in 2007 to tighten the criteria for recruiting new immigrants, requiring good language skills, a sufficient knowledge of French history and acceptance of the dominant norms and values. These changes bear witness to a certain "return of assimilation" observed in several West European 
countries since the 1990s (Brubaker 2001). A similar trend can be observed in the rules to obtain French citizenship. Candidates must prove that they support Republican values and agree with dominant cultural standards, even in their private life. There is a trend for confusing nationality with national identity (Weil 2008).

\section{Conclusion}

These selection criteria for immigrants and French citizens allow the re-emergence of the idea of assimilability by distinguishing people on a cultural basis. This is an inversion of the Republican model of integration. Obviously, integration policy is unable to succeed when ways of ensuring social cohesion are partly weakened by economic and social changes. The purpose of French integration policy was to prevent social norms from decaying. Yet, the policy has probably been developed too late and has not found the right path to success. Its failure is particularly dramatic in its most emblematic field, the Politique de la ville, an urban policy initiated at the end of the 1970s to counter urban segregation.

In spite of the various programmes of this territorialized social policy, urban segregation has worsened in France in recent decades (Fitoussi et al. 2004), and concerns not only concern the classes populaires but also the middle classes (Maurin 2004). The social stratification of a residential district or area determines access to quality education and subsequently further upward social mobility for the individuals who live there. Furthermore, this residential segregation in French cities increasingly implies an ethnic dimension, given the difficulties that residents have in sharing the same environment with different groups.

In some urban districts, relations can only be governed by violence and those living there cannot experience upward social mobility. They wonder what integration means (Kokoreff and Lapeyronnie 2013: 83-85). The fact of cohabiting with residents of a poor neighbourhood and sharing their social problems leads them to social behaviours that are too different from those of the middle classes or society "as a whole".

In contrast, residents living in urban districts where they encounter diverse components of that society can take opportunities to assimilate themselves to dominant cultural codes and share values, so creating possibilities for themselves for upward social mobility. Thus, the process of integration seems largely independent of integration policies, and remains strongly dependant on the local economic, social and cultural context. Urban segregation is a spatial expression of decreasing social cohesion and of an absence of global solidarity; or, inversely and as Durkheim demonstrated, integration is only possible in a 
society that retains its cohesion as a whole - if this holistic view is still possible in West European societies that are characterized by high social differentiation and the persistence of social and urban inequality.

\section{Bibliography}

Bachmann, C., 1989. Mise en image d'une banlieue ordinaire. Stigmatisations urbaines et stratégies de communication. Paris: Syros.

Barou, J., 2012. Country Monographs: France. In: C. Attias-Donfut, J. Cook, J. Hoffman and L. Waite, eds. Citizenship. Belonging and Intergenerational Relations in African Migration. Basingstoke: Palgrave Macmillan, 85-108.

Beaud, S. and Amrani, Y., 2004. Pays de malheur! Un jeune de cité écrit à un sociologue. Paris: La Découverte.

Benbassa, E., 2011. Minorités visibles en politique. Paris: CNRS Editions.

Brubaker, R., 2001. The return of assimilation? Changing perspectives on immigration and its sequels in France, Germany, and the United States. Ethnic and Racial Studies, 24 (4), 531548.

CAS (Centre d'analyse stratégique), Working Paper No. 6: Employment and business migrants 11/03/12. Available from: http://www.strategie.gouv.fr/en/content/working-paperno-6-employment-and-business-migrants [Accessed 20 February 2013].

De Rudder, V., Poiret, C. and Vourc'h, F., 2000. L'inégalité raciste: l'universalité républicaine à l'épreuve. Paris: Presses universitaires de France.

Donzelot, J, 1991. Face à l'exclusion, le modèle français. Esprit: Paris.

Doytcheva, M., 2005. Le multiculturalisme. Paris: La Découverte. 
Dubet, F, 1987. La galère, jeunes en survie. Paris: Le Seuil.

Dubet, F. and Lapeyronnie, D., 1992. Les quartiers d'exil. Paris: Le Seuil.

Durkheim, E., 1951 (orig. 1897). Suicide: A Study in Sociology. Translated by J.A. Spaulding and G. Simpson. Glencoe, Illinois: The Free Press of Glencoe. Translation of 1897, republished in 1952. London: Routledge and Kegan Paul.

Durkheim, E., 1984 (orig. 1893). The Division of Labour in Society. Translated by W.D. Halls (translation of 1893 [1902]). New York: The Free Press.

Durkheim, E., 1995 (orig. 1912). The elementary forms of religious life. A new translation by K.E. Fields. New York: The Free Press.

Estèbe, P. and Donzelot, J., 2004. L'usage des quartiers. Action publique et géographie dans la politique de la ville (1982-1999). Paris: L’Harmattan.

Favell, A., 1998. Philosophies of Integration: Immigration and the Idea of Citizenship in France and Britain. New York: St Martin's Press.

Fitoussi, J.-P., Laurent, E. and Maurice, J., 2004. Ségrégation urbaine et intégration sociale. Conseil d'analyse économique. Paris: La Documentation française.

HCI (Haut Conseil à l'Intégration), 2011. Intégrer dans une économie de sous-emploi. Info migrations. No. 23 (Mai).

Héran, F., 2010. Inégalités et discriminations: pour un usage critique et responsable de l'outil statistique. Rapport du comité pour la mesure de la diversité et l'évaluation des discriminations, Paris: La Documentation française.

INED and INSEE, 2010. Trajectoire et origine, enquête sur la diversité de la population en France, Paris: Editions de l'INED.

INSEE, 2001. Recensement de la population 1962-1999: Evolution et structure de la population immigrée selon le pays d'origine. www.insee.fr 
INSEE, 2005. Les immigrés en France: une situation qui évolue. INSEE première, no. 1042.

INSEE, 2008. France, portrait social. Paris: Collection INSEE Références.

Kazal, R.A., 1995. Revisiting Assimilation. The Rise, Fall and Reappraisal of a Concept in American Ethnic History. American Historical Review. Vol. 100, No.2, 437-471.

Kepel, G., 1997 (orig. 1994). Allah in the West: Islamic Movements in America and Europe. Stanford, Calif.: Stanford University Press.

Kokoreff, M. and Lapeyronnie, D., 2013. Refaire la cite. L'avenir des banlieues. Paris: Le Seuil.

Lagrange, H. and Oberti, M., 2006. Emeutes urbaines et protestations: une singularité française. Paris: Presses de Sciences Po.

Laurens, S, 2009. Une politisation feutrée. Les hauts fonctionnaires et l'immigration en France (1962-1981). Paris: Belin.

Maurin, E., 2004. Le ghetto français. Enquête sur le séparatisme social. Paris: Le Seuil.

Noiriel, G., 1988. Le creuset français. Histoire de l'immigration XIXe-XXe siècle. Paris: Le Seuil.

O'Leary, B. and McGarry, J., 2012. The Politics of Accommodation and Integration in Democratic States. In: A. Guelke and J. Tournon, eds. The Study of Politics and Ethnicity: Recent Analytical Developments. Leverkusen Opladen: Barbara Budrich Publishers, 79-116.

Pew Research Center, 2006. Muslims in Europe: Economic Worries Top Concerns About Religious and Cultural Identity.

Available from: http://www.pewglobal.org/2006/07/06/muslims-in-europe-economic-worriestop-concerns-about-religious-and-cultural-identity [Accessed 20 February 2013]. 
Sayad, A., 1999. La double absence. Des illusions de l'émigré aux souffrances de l'immigré. Paris: Le Seuil.

Schnapper, D., 2007. Qu'est-ce que l'intégration? Paris: Gallimard.

Schor, R., 1985. L'opinion française et les étrangers en France (1919-1939). Paris: Les publications de la Sorbonne.

Simmel, G., 2009 (orig. 1908). The Intersection of Social Circles. In: G. Simmel, Sociology: Inquiries into the Construction of Social Forms, volume 2, chapter six. Translated and edited by A.J. Blasi, A.K. Jacobs and M. Kanjirathinkal. Leiden: Brill, 363-408.

Simon, P., 2008. Les statistiques, les sciences sociales françaises et les rapports sociaux ethniques et de « race » ». Revue française de sociologie, No. 1, Vol. 49, 153-162.

Tribalat, M., 1995. Faire France: Une enquête sur les immigrés et leurs enfants. Paris: La Découverte.

Verret, M., 1999. Le travail ouvrier. Paris: L’Harmattan.

Weil, P., 2003. Races at the Gate. Racial Distinctions in Immigration Policy: A Comparison between France and the United States. In: A. Farhmeir, O. Faron and P.Weil, eds. From Europe to North America. Migration Control in the Nineteenth Century. The Evolution of States Practices in Europe and the United States from the French Revolution to the Inter-War Period. New York and London: Berghahn Books, 368-402.

Weil, P., 2005. La France et ses étrangers. L'aventure d'une politique de l'immigration de 1938 à nos jours. Paris: Gallimard.

Weil, P., 2008 (orig. 2002). How to Be French. Nationality in the making since 1789. Durham, NC: Duke University Press.

Weil, P., 2011. Etre français, les quatre piliers de la nationalité. Paris: Editions de l'Aube. 
Wieviorka, M., 2001. La différence. Paris: Balland.

Wihtol de Wenden, C., 2003. Multiculturalism in France. International Journal on

Multicultural Societies, vol. 5, no.1, 77-87. Available from:

http://www.unesco.org/shs/ijms/vol5/issue1/art5 [Accessed 20 February 2013].

\section{Notes}

\footnotetext{
${ }^{1}$ According to the French census, an immigrant is a person who came to France as foreigner. Some immigrants retain their foreign nationality while others obtain the French one, but remain statistically immigrants. Children of immigrants born in France are not considered as immigrants.

${ }^{2}$ However, the recent Socialist government of François Hollande favours ethnic statistics provided that two independent authorities agree: the Conseil Constitutionnel, which has to examine their concordance with Republican principles, and the Commission Nationale Informatique et Liberté, which has to protect the private data of citizens (interview with the Home Secretary Manuel Valls, Ouest France, 6 December 2012).

${ }^{3}$ Merriam-Webster's Collegiate Dictionary, 2008 (1 $1{ }^{\text {th }}$ edition). London: Encyclopedia Britannica company, 650.

${ }^{4}$ Foreigners in France. A geographical study of their role in the economy.

${ }^{5}$ Haut Conseil à l'Intégration, 1991. Pour un modèle français d'intégration. Paris: La Documentation française.

${ }^{6}$ Haut Conseil à l'Intégration, 2005. Bilan de la politique d'intégration 2002-2005. Paris: La Documentation française.
} 